\title{
Karlheinz Stockhausen
}

\author{
Entrevista concedida a \\ J. Jota de Moraes
}

Não foi muito fácil conseguir uma entrevista com o compósitor alemão Karlheinz Stockhausen. Participando no Rio de Janeiro de uma maratona de sete concertos, ensaiando exaustivamente todos os dias, ele geralmente ś́ oferecia 15 minutos anteriores aos espetáculos para quem quisesse conversar com ele.

Assim, foi com um riso incrédulo e uma exclamaçāo ("voce está louco, o homem só quer saber de trabalho") que a compositora Jocy de Oliveira recebeu o meu pedido: duas horas do tempo do artista. Ele me olhou seriamente, consultou a sua agenda germanicamente organizada e encontrou o tempo perdido no final da tarde do domingo.

Quando Stockhausen chegou à sala Cecília Meireles, perto dos arcos da Lapa, eu ja o esperava à maneira paulista - com meia hora de antecedência. Muito cordial, ele subiu e desceu várias escadas até conseguirmos um bom lugar para a conversa, uma sala empoeirada da administração do teatro. Instalando-se em uma cadeira diante da minha, ele demonstrou estar com um ótimo ânimo. Nem parecia ser o mesmo homem que, alguns dias antes, tinha feito chorar a sua pianista e deixado os instrumentistas com os nervos à flor da pele, por causa das suas exigências. Nada autoritário, ele agora conversava com indisfarçável prazer, confessando não saber o porquê de nāo ter vindo ao Brasil, vinte anos antes.

Até o momento, a única referência à música brasileira encontrável em sua obra é a do canto de uma índia do Xingu em "Telemusik", de 1966. Como o conheceu?

Eu estava no Japão. Pedi que me conseguissem música original de várias regiổes - da Africa, da Indochina, de Bali... Foram postos à minha disposição vários materiais, como a música da corte chinesa, da região montanhosa do Vietnã e essa canção de ninar de uma índia da Amazônia.
Seria capaz de lembrar-se da impressão causada por esse Ur-Musik, por essa música primeva?

Foi muito forte. Essa coisa da origem do homem sempre me toca profundo.

Dois anos depois de "Telemusik", apareceu "Stimmung", em 1968. O canto da india brasileira, um som longamente sustentado com poucas variações de alturas, pareceu-me semelhante à idéia central dessa nova obra, baseada em um som e em seus harmônicos. Não digo tecnicamente, mas como "clima poético", "Stimmung" nâo teria algo a ver com a canção de ninar brasileira?

Acho que em outras obras minhas há relações maiores com os sons da origem. "Momento", por exemplo, está cheio dessas coisas. E tamberm "Hymnen", sobretudo na segunda e na quarta regióes. Utilizo esses fragmentos de cultura para integrá-los a outros materiais em minhas obras.

Houve na época dessa obras uma reaçāo muito negativa, da parte de alguns críticos $e$ compositores, em relação ao uso da música folclórica em peças eletroacústicas.

$\mathrm{Ah}$, sem dúvida... Luigi Nono chegou a falar até mesmo em imperialismo da minha parte... Depois, eu mesmo havia dito, dez anos antes, que para escrever música era preciso inventar tudo, não utilizar nada do que já tivesse sido ouvido. Mas eu mudara de opinião. Passara a ver que era preciso equilibrar, na música, o conhecido e o desconhecido. Em "Hymnen" eu utilizei vários hinos nacionais, porque cada um conhece bem o hino de seu próprio país - pelo menos o seu começo. Utilizei esse material como base da mutação, da transformação dos fenômenos. Como personagens.

Até que ponto a utilização do material folclórico não pode ser vista como um gosto 
anti-serial, na medida em que Schoenberg sempre foi contra o que ele chamava de "sinfonias folcloristas'? Até que ponto considera-se um artista serial?

No início vi o serialismo de maneira mais estrita. Depois, generalizei esse conceito, passando a encarar a série não mais como um ponto (de som), mas como figuras. As figuras são mais ricas. Crio as minhas próprias figuras e submeto-as à compressão, à transfiguraçāo, à microanálise e à projeção macromusical, projetando os sons especialmente. Acredito que o serialismo nảo $\ell$ outra coisa que a teoria da relatividade musical. $\mathrm{E}$, nessa nova alquimia, por que nāo utilizar o passado do homem para construir a música do futuro do homem? Mas acho horrível a utilização do passado como simples "molho". A destruição ou a distorção da arte do passado é um simples gesto. No meu caso trata-se de integrar esses materiais, de colocá-los em relação com novos fenômenos. Mas é preciso saber utilizar esses materiais, pois quando o passado for mais forte, $o$ compositor morre...

Um dos seus colaboradores da década de 1960, o já falecido compositor inglês Cornelius Cardew, escreveu mais tarde um artigo intitulado "Stockhausen serve ao imperialismo"'. Lembra-se disso?

$\mathrm{Ah}$, sim, eu estava em Londres quando o livro foi lançado. E o título foi pensado para que ele vendesse bem... Sempre gostei de Cardew, mas seus argumentos eram muito pobres, com toda aquela coisa de que toda a música era autoritária... Não admito que coloquem o casaco da política sobre meus ombros. Para o músico, a política é sempre uma desculpa. Quem se lembra, hoje, da "Vitória de Wellington na batalha de Vitória" de Beethoven? $\mathrm{O}$ músico é um artesāo que lida com sons.

Em relação às suas obras eletrônicas ou eletroacústicas, penso que "Cântico dos Adolescentes," de 1956, é bem mais rica e complexa do que algumas de suas obras atuais nesse campo, como as mostradas neste festival. Concorda comigo?

Não. Elas também são bastante complexas, com contrapontos a sete ou oito vozes como em "Aries", que você ouviu outra noite.

\section{Quais são atualmente as suas relaçōes com a tecnologia? \\ Acabei de fazer um curso, junto a meu} filho Simon e dois outros auxiliares, de programação de sintetizadores. Foi um trabalho enorme. Preocupei-me sobretudo com a pro- gramação de timbres. Não utilizo mais orquestra, apenas sintetizadores. Quando tenho à minha disposição instrumentistas de alto nível, como acontece agora, escrevo para solistas. Caso contrário, escrevo para sintetizadores, obtendo resultados mais precisos no que tange ao timbre e à dinâmica e, sobretudo, à espacialização do som. Não. Não creio que o resultado soe pasteurização. $O$ som conseguido através de sintetizadores é muito mais concentrado do que o de uma orquestra. Posso com eles conseguir efeitos de massa e de ondas sonoras que se projetam no espaço.

Ouvindo algumas obras suas bem recentes - "O Pequeno Arlequim", "Áries", "Zodíaco" - tive a impressão de que há aí uma espécie de volta à melodia...

Eu sempre fui melódico. Desde "Cântico dos Adolescentes" e mesmo antes, com "Três Cançōes", de 1950. Acho muito importante a melodia e, cada vez mais, torno-me mais melódico. E há algumas situaçōes que exigem isso. Por exemplo, em minha ópera "Segunda-feira", do projeto "Luz", há várias passagens escritas para coro infantil. Assim, para coro de até 36 vozes diferentes, tive que escrever música bem melódica e cantável. E resultou bem...

Em sua peça " $O$ Sonho de Lúcifer", que pertence à b́pera "Sábado", do projeto "Luz", são colocados em cena uma pianista e um cantor, um baixo. Mas a parte do piano dá a impressão de poder ser mostrada sozinha.

De fato, ela é minha "Peça para Piano XIII". Aliás, uso o piano aí como um sofá, um divã... O instrumentista se instala nele com glissandos enormes que percorrem grandes porçōes do teclado. Nāo tendo mais o que fazer nas teclas, o pianista vai diretamente para as cordas e até se senta sobre o teclado... Historicamente, o piano acabou. Essa peça poderia ser chamada de "Réquiem do Piano"...

Mesmo depois de encerrada a entrevista, Karlheinz Stockhausen ainda sente vontade de falar:

"Viu o que a orquestra de Stuttgart está tocando no Brasil? Beethoven, Mendelssohn, Ravel... tudo bem antigo, velho. Nada de música contemporânea. As pessoas não ouvem música contemporânea e, por isso, por não estarem acostumadas a ela, não gostam. E como as orquestras tocam pouco música moderna, quando fazem isso, tocam mal. Isso é bem um sinal da decadência artística. É igual em todo lugar - na Europa e aqui. Até o final do século 19 ouvia-se música moderna. Agora 
é diferente. Veja uma figura como a de Leonard Bernstein. Ele não toca música moderna porque não gosta. E coloca a culpa de não tocá-la, no público. Mas ele tem um gosto horroroso - veja como ele toca Mahler, todo empolado."

Nota: Essa entrevista foi publicada no Jornal da Tarde de 19.7.88. 